\title{
A Microperfusion Study of Bicarbonate Accumulation in the Proximal Tubule of the Rat Kidney*
}

\author{
Norman Bank † and Hagop S. Aynedjian \\ (From the Department of Medicine, New York University School of Medicine, \\ New York, N.Y.)
}

\begin{abstract}
Summary. In order to determine whether $\mathrm{HCO}_{3}^{-}$gains access to the proximal tubular lumen from a source other than the glomerular filtrate, we carried out microperfusion experiments on isolated segments of rat proximal tubules in vivo. The perfusion fluid was essentially free of $\mathrm{HCO}_{3}^{-}$and of a composition that prevented net absorption of sodium and water.

It was found that when plasma $\mathrm{HCO}_{3}^{-}$concentration and $\mathrm{CO}_{2}$ tension $\left(\mathrm{PCO}_{2}\right)$ were normal, the $\mathrm{HCO}_{3}{ }^{-}$concentration in the collected perfusate rose to about $3 \mathrm{mEq}$ per $\mathrm{L}$. Inhibition of renal carbonic anhydrase did not produce an appreciable change in this value in normal rats, but when the enzyme was inhibited in acutely alkalotic rats, a mean concentration of $15 \mathrm{mEq}$ per L was recovered in the perfusate. Addition of $\mathrm{HCO}_{3}{ }^{-}$to the tubular lumen might occur by either intraluminal generation of $\mathrm{HCO}_{3}^{-}$from $\mathrm{CO}_{2}$ and $\mathrm{OH}^{-}$or by influx of ionic bicarbonate from the plasma or tubular cells. Because of the marked increase in $\mathrm{HCO}_{3}{ }^{-}$found when intraluminal carbonic anhydrase was inhibited, generation of new $\mathrm{HCO}_{3}^{-}$from $\mathrm{CO}_{2}$ and $\mathrm{OH}^{-}$seems unlikely. We conclude, therefore, that influx of ionic bicarbonate occurred, either across the luminal membrane or through extracellular aqueous channels. These observations suggest that the proximal epithelium has a finite degree of permeability to $\mathrm{HCO}_{3}^{-}$and that influx of this ion may be a component of the over-all handling of $\mathrm{HCO}_{3}^{-}$by the kidney.
\end{abstract}

\section{Introduction}

Reabsorption of bicarbonate by the proximal and distal convoluted tubules of the rat kidney has been shown to be mediated by active secretion of $\mathrm{H}^{+}$by the lining epithelial cells (1). Bicarbonate ions in the tubular lumen react with secreted $\mathrm{H}^{+}$to form $\mathrm{H}_{2} \mathrm{CO}_{3}$, which then decomposes into $\mathrm{CO}_{2}$ and $\mathrm{H}_{2} \mathrm{O}$. It has generally been assumed that all of the $\mathrm{HCO}_{3}^{-}$taking part in the

* Submitted for publication May 24, 1966; accepted September 22, 1966.

Supported by grants from the National Heart Institute (HE 05770-06) and the Life Insurance Medical Research Fund.

$\dagger$ Career Scientist of the Health Research Council of New York.

Address requests for reprints to Dr. Norman Bank, Dept. of Medicine, New York University School of Medicine, 550 First Ave., New York, N. Y. 10016. reactions in the tubular lumen is derived from the plasma by glomerular filtration. Recent studies have demonstrated, however, that the proximal epithelium of the rat kidney has a high degree of permeability to certain ions, allowing a significant influx of sodium $(2,3)$, chloride (2), and potassium (4) into the tubular lumen. The possibility must be considered, therefore, that $\mathrm{HCO}_{3}{ }^{-}$ also enters the tubular lumen from a source other than the glomerular filtrate. If it does, the overall processes of net reabsorption and excretion of $\mathrm{HCO}_{3}^{-}$by the kidney might be subject to variables that have not previously been evaluated by clearance measurements.

In the experiments reported here, the question of addition of $\mathrm{HCO}_{3}{ }^{-}$to the tubular fluid distal to the glomerulus was studied in rats by perfusing isolated segments of cortical proximal tubules in vivo with a $\mathrm{HCO}_{3}^{-}$-free solution. Upon col- 
lection of the perfusate, $\mathrm{pH}$ was measured with a quinhydrone microelectrode under conditions of known $\mathrm{PCO}_{2}$, and the $\mathrm{HCO}_{3}^{-}$concentration calculated from the Henderson-Hasselbalch equation. It was found that when plasma $\mathrm{HCO}_{3}{ }^{-}$concentration and $\mathrm{PCO}_{2}$ were normal, the concentration of $\mathrm{HCO}_{3}{ }^{-}$in the perfusate rose to about $3 \mathrm{mEq}$ per L. Inhibition of carbonic anhydrase did not alter this value significantly, but when the enzyme was inhibited in acutely alkalotic rats, a mean $\mathrm{HCO}_{3}{ }^{-}$concentration of $15 \mathrm{mEq}$ per $\mathrm{L}$ was found in the perfusate. On the basis of these observations we conclude that the bicarbonate found in the perfusate had entered the proximal lumen in the ionic form. Permeability of the proximal epithelium to $\mathrm{HCO}_{3}^{-}$suggests that flux of this ion may be a component of the over-all handling of bicarbonate by the kidney.

\section{Methods}

Male white rats weighing 200 to $300 \mathrm{~g}$ were anesthetized with Inactin [sodium ethyl-( $l$-methylpropyl)-thiobarbiturate], tracheotomized, and placed on a heated animal table. The left external jugular vein was cannulated with polyethylene tubing for infusion of solutions and drug administration. The left kidney was exposed through a lateral abdominal incision, dissected free of perirenal fat tissue, and immobilized in a plastic cup packed with vaseline. The surface of the kidney was bathed in mineral oil flowing continuously from a Knisely quartz rod illuminator. Blood samples were obtained from the abdominal aorta at the beginning and end of most experiments or, in a few cases, only at the end of the experiment.

In two groups of animals, plasma $\mathrm{HCO}_{3}{ }^{-}$concentration was maintained within normal limits by intravenous infusion of the following solution at $0.1 \mathrm{ml}$ per minute: $\mathrm{NaCl}, 125$ mmoles per L; $\mathrm{NaHCO}_{3}, 25$ mmoles per $\mathrm{L}$. In the second group of rats, $2 \mathrm{mg}$ per $\mathrm{kg}$ body weight of the carbonic anhydrase inhibitor, 2-benzenesulfonamide1,3,4-thiadiazole-5-sulfonamide (CL 11,366), 1 was administered intravenously 15 minutes before microperfusion of the surface tubules was started. In this group, the drug was also added to the perfusion solution in a concentration of $0.01 \mathrm{mg}$ per $\mathrm{ml}$. In a third and fourth group of rats, plasma $\mathrm{HCO}_{3}^{-}$concentration was elevated by intravenous infusion of $0.15 \mathrm{M} \mathrm{NaHCO}$ at 0.1 to 0.2 $\mathrm{ml}$ per minute for 1 hour before microperfusion of the surface nephrons and sustained by continuous infusion throughout the experiment. In the fourth group of animals, CL 11,336 was administered as described above.

The surface proximal tubules were perfused by a mi-

1 The CL 11,366 was generously supplied by Wallace Labs., Cranbury, N. J. cropipette mounted on a continuous microperfusion pump of the type described by Sonnenberg and Deetjen (5). The perfusion solution had the following composition: $\mathrm{NaCl}, 90$ mmoles per $\mathrm{L}$; mannitol, 110 mmoles per L; $\mathrm{NaH}_{2} \mathrm{PO}_{4}, 1$ mmole per $\mathrm{L}$; lissamine green, $1 \mathrm{~g}$ per L; trace amounts of ${ }^{14} \mathrm{C}$-labeled inulin. ${ }^{2}$ It was equilibrated with $5 \% \mathrm{CO}_{2}$. The $\mathrm{pH}$ was between 5.1 and 5.3 , small variations being due to differences among tanks of $\mathrm{CO}_{2}$. The rate of injection was between 12 and $20 \mathrm{nl}$ per minute, which is within the normal range of tubular fluid flow (6). Two different techniques were used to achieve isolation of the perfused segments, but the results were found to be the same with the two methods. In about half of the perfusions, a small amount of heavy castor oil colored with Sudan black was injected into the lumen of a proximal tubule with a collecting pipette and the direction of flow determined by the spontaneous movement of the oil. Several segments of the nephron were then completely filled with the oil and the pipette was withdrawn, leaving a hole in the tubule wall for escape of fluid coming from the glomerulus. The same pipette was next reinserted into the most distal segment of the oil-filled tubule. The perfusion pipette was then inserted in a more proximal portion of the oil column and the perfusion started. As the entering perfusion fluid split the oil column, negative pressure was applied to the collecting pipette until the perfusion fluid reached it. A slight readjustment of the pressure on the collecting pipette was then made so that both the proximal and distal oil blocks remained in a fixed position as the perfusion fluid flowed into the collecting pipette. The second technique was that described by Marsh and Frasier (7). The direction of tubular fluid flow was determined as above by injecting a small amount of castor oil from the collecting pipette. With this pipette still in position, the perfusing pipette was inserted into the next segment of the tubule, and perfusion was started. Oil was then injected proximal to the perfusion pipette to provide the proximal block; the collecting pipette was withdrawn. After a few minutes of perfusion, the collecting pipette was reinserted into the most distal segment of the perfused proximal tubule, oil was injected and allowed to flow distally a short distance, and collection was started by adjustment of the pressure on this pipette. With both methods of perfusion, constant attention to the pressure on the collecting pipette was necessary to maintain the two oil blocks in proper position.

The collected perfusate was immediately transferred to a siliconized glass cup freshly filled with mineral oil equilibrated with $5 \% \quad \mathrm{CO}_{2}$. Approximately 5 minutes was allowed for the sample to equilibrate with the surrounding oil, after which time about 0.01 to $0.03 \mu 1$ was aspirated into a quinhydrone microelectrode filled with the same $\mathrm{CO}_{2}$-equilibrated mineral oil. The $\mathrm{pH}$ was measured at $37^{\circ} \mathrm{C}$ as previously described (8) and the concentration of $\mathrm{HCO}_{3}{ }^{-}$calculated from the $\mathrm{pH}$ and the $\mathrm{PCO}_{2}$ by the Henderson-Hasselbalch equation with a $\mathrm{pK}$ of 6.1 and a $\mathrm{CO}_{2}$ conversion factor of 0.0309 mmoles per $\mathrm{mm} \mathrm{Hg}$. The $\mathrm{P}_{\mathrm{CO}_{2}}$ of the mineral oil and of the original

2 New England Nuclear Corp., Boston, Mass. 
TABLE I

Simulated experiments on $p H$ of perfusion fluid measured with glass and quinhydrone electrodes at $37^{\circ} \mathrm{C}$

\begin{tabular}{|c|c|c|c|c|}
\hline \multirow{2}{*}{$\begin{array}{l}\text { Added } \\
\mathrm{HCO}_{3}^{-}\end{array}$} & \multicolumn{2}{|c|}{ Glass electrode } & \multicolumn{2}{|c|}{ Quinhydrone electrode } \\
\hline & $\mathrm{pH}$ & Calculated $\mathrm{HCO}_{3}{ }^{-*}$ & $\mathrm{pH}$ & Calculated $\mathrm{HCO}_{3}-$ \\
\hline$m E q / L$ & & $m E q / L$ & & $m E q / L$ \\
\hline $\begin{array}{l}0 \\
5.0 \\
15.0\end{array}$ & $\begin{array}{l}5.18 \pm 0.01(9) \dagger \\
6.58 \pm 0.01(8) \\
7.09 \pm 0.01(8)\end{array}$ & $\begin{aligned} 0.17 & \pm 0.01 \\
4.8 & \pm 0.1 \\
15.4 & \pm 0.3\end{aligned}$ & $\begin{array}{l}5.15 \pm 0.05(12) \\
6.55 \pm 0.06(10) \\
7.12 \pm 0.06(11)\end{array}$ & $\begin{array}{c}0.17 \pm 0.03 \\
4.4 \pm 0.5 \\
16.5 \pm 1.8\end{array}$ \\
\hline
\end{tabular}

* The $\mathrm{CO}_{2}$ tension $\left(\mathrm{PCO}_{2}\right)$ of the solutions used in the calculation of $\mathrm{HCO}_{3}{ }^{-}$concentration was measured with an Instrumentation Laboratory $\mathrm{PCO}_{2}$ electrode and was found to range between 44 and $51 \mathrm{~mm} \mathrm{Hg}$ with different tanks of $5 \% \mathrm{CO}_{2}$.

$\dagger$ Data expressed as mean \pm standard deviation. The numbers in parentheses are the number of measurements.

perfusion fluid was determined directly at $37^{\circ} \mathrm{C}$ with an Instrumentation Laboratory $\mathrm{PCO}_{2}$ electrode, correction being made for the ambient barometric pressure.

The remainder of the sample was transferred to a constant bore capillary tube under microscopic visualization and the volume determined with an eyepiece micrometer, as described by Windhager and Giebisch (9). The sample was then delivered from the capillary tube into a dioxane-containing counting vial, and radioactivity was measured with a Nuclear Chicago liquid scintillation counter (Unilux). Radioactivity in the original perfusion solution was measured by the same method.

Blood $\mathrm{pH}$ was measured at $37^{\circ} \mathrm{C}$ with a capillary glass electrode and Metrohm $\mathrm{pH}$ meter, model $\mathrm{E} 322$. Plasma $\mathrm{CO}_{2}$ content was measured with a Natelson microgasometer, and $\mathrm{PCO}_{2}$ and $\mathrm{HCO}_{3}{ }^{-}$concentration were calculated from the Henderson-Hasselbalch equation.

\section{Results}

In Table I are shown the results of simulated perfusion experiments. The perfusion fluid was delivered from the microperfusion pump into a glass cup filled with $\mathrm{CO}_{2}$-equilibrated mineral oil and simultaneously aspirated in a collecting pipette. The fluid was then redelivered from the collecting pipette into the oil, allowed to equilibrate for 5 minutes, and finally taken up in a pipette containing a quinhydrone microelectrode. The entire time period closely approximated that required for perfusion of the tubules in the actual experiments. As can be seen, over the range of $\mathrm{pH}$ values and $\mathrm{HCO}_{3}{ }^{-}$concentrations studied, there was close agreement between the quinhydrone and glass electrode measurements. We conclude from these observations that the methods used to equilibrate the perfusate with $\mathrm{CO}_{2}$ and determine its $\mathrm{HCO}_{3}{ }^{-}$ concentration were accurate and reproducible.

The data obtained from 16 tubular perfusions in 7 normal rats are shown in Table II. The collected perfusate in all instances showed an in- crease in $\mathrm{HCO}_{3}{ }^{-}$concentration from about 0.2 $\mathrm{mEq}$ per $\mathrm{L}$ in the original solution to a mean of $2.7 \mathrm{mEq}$ per $\mathrm{L}$. The in vitro $\mathrm{pH}$ values shown in column 5 are probably slightly lower than was the $\mathrm{pH}$ in vivo, since the tension of $\mathrm{CO}_{2}$ with which the samples were equilibrated was higher than most of the plasma $\mathrm{PcO}_{2}$ values. This should not, however, affect the determination of $\mathrm{HCO}_{3}^{-}$ concentration (1). That there was no net water absorption during the perfusion period is indicated by the collected/injected inulin ratios

TABLE II

Bicarbonate concentration in collected perfusate after passage through isolated segments of the proximal convoluted tubule*

\begin{tabular}{|c|c|c|c|c|c|c|}
\hline \multirow{2}{*}{$\begin{array}{c}\text { Experi- } \\
\text { ment } \\
\text { no. }\end{array}$} & \multicolumn{3}{|c|}{ Plasma } & \multicolumn{2}{|c|}{ Collected perfusate } & \multirow{2}{*}{$C / I_{\ln } \dagger$} \\
\hline & $\mathrm{pH}$ & {$\left[\mathrm{HCO}_{3}-\right]$} & $\mathrm{PCO}_{2}$ & $\mathrm{pH}$ & {$\left[\mathrm{HCO}_{3}^{-}\right]$} & \\
\hline & & $m E q / L$ & $m m H g$ & & $m E q / L$ & \\
\hline 1 & 7.36 & 21.5 & 39 & $\begin{array}{l}6.58 \\
6.50\end{array}$ & $\begin{array}{l}4.0 \\
3.3\end{array}$ & $\begin{array}{l}0.97 \\
0.99\end{array}$ \\
\hline 2 & 7.24 & 19.1 & 46 & 6.63 & 4.8 & 0.91 \\
\hline 3 & 7.27 & 22.3 & 50 & $\begin{array}{l}6.43 \\
6.77\end{array}$ & $\begin{array}{l}3.0 \\
6.7\end{array}$ & $\begin{array}{c}0.98 \\
0.98\end{array}$ \\
\hline 4 & 7.41 & 20.3 & 33 & $\begin{array}{l}6.01 \\
6.61\end{array}$ & $\begin{array}{l}1.2 \\
4.6\end{array}$ & $\begin{array}{l}0.98 \\
1.02\end{array}$ \\
\hline 5 & 7.36 & 20.9 & 38 & $\begin{array}{l}6.09 \\
5.98\end{array}$ & $\begin{array}{l}1.4 \\
1.1\end{array}$ & $\begin{array}{l}0.98 \\
1.01\end{array}$ \\
\hline , & 7.31 & 18.8 & 39 & 6.25 & 2.0 & 1.01 \\
\hline 6 & 7.41 & 21.1 & 39 & $\begin{array}{l}6.11 \\
6.07 \\
5.88\end{array}$ & $\begin{array}{l}1.4 \\
1.3 \\
0.8\end{array}$ & $\begin{array}{l}1.03 \\
0.99 \\
1.04\end{array}$ \\
\hline 7 & $\begin{array}{l}7.40 \\
7.36\end{array}$ & $\begin{array}{l}17.6 \\
18.9\end{array}$ & $\begin{array}{l}33 \\
35\end{array}$ & $\begin{array}{l}6.19 \\
6.35 \\
6.51\end{array}$ & $\begin{array}{l}1.7 \\
2.4 \\
3.5\end{array}$ & $\begin{array}{l}0.97 \\
1.04 \\
0.99\end{array}$ \\
\hline $\begin{array}{l}\text { Mean } \\
\pm S D\end{array}$ & & & & $\begin{array}{l}6.31 \\
0.26\end{array}$ & $\begin{array}{l}2.7 \\
1.6\end{array}$ & $\begin{array}{l}0.99 \\
0.03\end{array}$ \\
\hline
\end{tabular}

* Bicarbonate concentrations of the perfusate were calculated from the Henderson-Hasselbalch equation, with the $\mathrm{pH}$ measured at a known $\mathrm{PCO}_{2}$.

$+\mathrm{C} / \mathrm{IIn}_{\mathbf{n}}=$ ratio of inulin concentration of collected perfusate to that of injected perfusion fluid. 
TABLE III

Effect of carbonic anhydrase inhibition on bicarbonate concentration of collected perfusate*

\begin{tabular}{|c|c|c|c|c|c|c|}
\hline \multirow{2}{*}{$\begin{array}{c}\text { Experi- } \\
\text { ment } \\
\text { no. }\end{array}$} & \multicolumn{3}{|c|}{ Plasma } & \multicolumn{2}{|c|}{ Collected perfusate } & \multirow[b]{2}{*}{$\mathrm{C} / \mathrm{IIn}_{\mathrm{n}}$} \\
\hline & $\mathrm{pH}$ & {$\left[\mathrm{HCO}_{3}^{-}\right]$} & $\mathrm{PCO}_{2}$ & $\mathrm{pH}$ & {$\left[\mathrm{HCO}_{3}^{-}\right]$} & \\
\hline & & $m E q / L$ & $m m H g$ & & $m E q / L$ & \\
\hline 8 & 7.26 & 23.9 & 55 & 6.53 & 3.8 & 1.02 \\
\hline 9 & 7.24 & 19.1 & 46 & 6.63 & 4.8 & 0.99 \\
\hline \multirow[t]{4}{*}{10} & 7.30 & 19.8 & 41 & 6.61 & 4.1 & 1.00 \\
\hline & & & & 6.81 & 6.5 & 1.01 \\
\hline & & & & 6.87 & 7.5 & 1.00 \\
\hline & 7.42 & 22.2 & 35 & 6.62 & 4.2 & 1.02 \\
\hline \multirow[t]{4}{*}{11} & 7.32 & 22.2 & 44 & 6.46 & 2.9 & 1.00 \\
\hline & & & & 6.30 & 2.0 & 0.96 \\
\hline & & & & 6.42 & 2.7 & 1.02 \\
\hline & 7.48 & 25.5 & 35 & 6.51 & 3.3 & 0.99 \\
\hline \multirow[t]{5}{*}{12} & 7.21 & 20.1 & 52 & 6.64 & 4.4 & 1.01 \\
\hline & & & & 6.38 & 2.4 & 1.03 \\
\hline & & & & 6.56 & 3.7 & 0.99 \\
\hline & & & & 6.46 & 2.9 & 1.00 \\
\hline & 7.46 & 23.0 & 33 & 6.69 & 4.9 & 1.00 \\
\hline \multirow[t]{2}{*}{13} & 7.35 & 22.5 & 42 & 6.42 & 2.7 & 0.96 \\
\hline & & & & 6.20 & 1.6 & 0.95 \\
\hline Mean & & & & 6.54 & 3.8 & 1.00 \\
\hline$\pm \mathrm{SD}$ & & & & 0.14 & 1.5 & 0.07 \\
\hline
\end{tabular}

* Carbonic anhydrase was inhibited by intravenous and intraluminal administration of 2-benzenesulf onamide-1,3,4-thiadiazole-5-sufonamide (CL 11,366).

$\left(\mathrm{C} / \mathrm{I}_{\mathrm{In}}\right)$ shown in the last column. These data also serve to rule out the possibility of contamination of the perfusate with tubular fluid coming from the glomerulus or retrograde from other nephrons. Since net absorption of water was reduced to zero, bidirectional movement of sodium was presumably in a steady state condition. Bicarbonate ions, however, may not have reached their final steady state concentration during the perfusion. It has been found in "split oil drop" studies in which solutions low in $\mathrm{Na}^{+}$concentration were injected into isolated segments of the rat proximal tubule (3) that $\mathrm{Na}^{+}$concentration rises exponentially with time. In the first 10 seconds, the $\mathrm{Na}^{+}$concentration rose to about twothirds of its steady state concentration, but took about 50 to 60 seconds before it finally stabilized at 90 to $100 \mathrm{mEq}$ per L. In the present experiments, a rough approximation of the contact time of the perfusion fluid with the tubular epithelium can be made from the rate of perfusion $(15 \mathrm{nl}$ per minute), the mean tubular diameter $(24 \mu)$, and an average length of perfused nephron segment $(5 \mathrm{~mm})$. This calculation yields a time of contact of about 10 seconds. If $\mathrm{HCO}_{3}^{-}$accumulation occurs at a rate comparable to that of $\mathrm{Na}^{+}$influx, steady state concentrations of $\mathrm{HCO}_{3}{ }^{-}$would have been approached but not reached during the perfusion period, and the final concentrations would be even higher than those found. However, it seems unlikely that the true steady state $\mathrm{HCO}_{3}^{-}$ concentration is very much higher, since the value calculated from steady state $\left[\mathrm{Na}^{+}\right]+\left[\mathrm{K}^{+}\right]-\left[\mathrm{Cl}^{-}\right]$ in normal rats is approximately $4.5 \mathrm{mEq}$ per L (2).

In the second group of normal rats, shown in Table III, renal carbonic anhydrase was inhibited by intravenous and intraluminal injection of 2-benzenesulfonamide-1,3,4-thiadiazole-5sulfonamide (CL 11,366). This drug has been shown to have no significant effect on red blood cell carbonic anhydrase at the dose used here but to have a maximal effect on the kidney (10). Plasma $\mathrm{PCO}_{2}$ did not rise, therefore, as it does with acetazolamide administration; it actually fell in most of the experiments, probably due to a decrease in the depth of anesthesia and resultant

TABLE IV

Effect of $\mathrm{NaHCO}_{3}$ infusion on bicarbonate concentration of collected perfusate

\begin{tabular}{|c|c|c|c|c|c|c|}
\hline \multirow{2}{*}{$\begin{array}{c}\text { Experi- } \\
\text { ment } \\
\text { no. }\end{array}$} & \multicolumn{3}{|c|}{ Plasma } & \multicolumn{2}{|c|}{ Collected perfusate } & \multirow[b]{2}{*}{$\mathrm{C} / \mathrm{I}_{\mathrm{In}}$} \\
\hline & $\mathrm{pH}$ & {$\left[\mathrm{HCO}_{3}{ }^{-}\right]$} & $\mathrm{PcO}_{2}$ & $\mathrm{pH}$ & {$\left[\mathrm{HCO}_{2}^{-}\right]$} & \\
\hline & & $m E q / L$ & $m m \mathrm{Hg}$ & & $m E q / L$ & \\
\hline \multirow[t]{2}{*}{14} & 7.45 & 33.9 & 50 & 6.14 & 1.7 & 1.03 \\
\hline & 7.60 & 41.3 & 43 & 6.51 & 4.1 & 1.04 \\
\hline 15 & 7.35 & 36.4 & 68 & 6.46 & 3.6 & 1.03 \\
\hline \multirow[t]{2}{*}{16} & 7.52 & 35.3 & 45 & 6.69 & 6.1 & 1.03 \\
\hline & 7.74 & 51.9 & 40 & 6.59 & 4.9 & 1.02 \\
\hline \multirow[t]{5}{*}{17} & 7.42 & 27.2 & 43 & 5.90 & 1.0 & 1.02 \\
\hline & & & & 6.59 & 4.9 & 1.05 \\
\hline & & & & 6.79 & 7.7 & 1.01 \\
\hline & & & & 6.69 & 6.1 & 1.02 \\
\hline & 7.63 & 30.4 & 30 & 5.81 & 0.8 & 0.98 \\
\hline \multirow[t]{4}{*}{18} & 7.48 & 31.7 & 44 & 6.51 & 4.1 & 1.01 \\
\hline & & & & 6.58 & 4.8 & 1.01 \\
\hline & & & & 6.20 & 2.0 & 0.97 \\
\hline & 7.64 & 36.5 & 35 & 6.50 & 4.0 & 0.96 \\
\hline \multirow[t]{4}{*}{19} & 7.51 & 28.9 & 37 & 6.63 & 5.3 & 1.04 \\
\hline & & & & 6.45 & 3.5 & 1.01 \\
\hline & & & & 6.61 & 5.1 & 1.01 \\
\hline & 7.60 & 30.9 & 32 & 6.74 & 6.9 & 0.95 \\
\hline \multirow[t]{4}{*}{20} & 7.33 & 26.7 & 52 & 6.58 & 3.8 & 1.01 \\
\hline & & & & 6.61 & 4.1 & 1.04 \\
\hline & & & & 6.84 & 7.0 & 0.98 \\
\hline & 7.63 & 40.3 & 40 & 6.29 & 2.0 & 1.03 \\
\hline Mean & & & & 6.49 & 4.3 & 1.01 \\
\hline$\pm \mathrm{SD}$ & & & & $0.16^{\circ}$ & 1.9 & 0.06 \\
\hline
\end{tabular}


TABLE V

Effect of carbonic anhydrase inhibition and $\mathrm{NaHCO}_{3}$ infusion on bicarbonate concentration of collected perfusate*

\begin{tabular}{|c|c|c|c|c|c|c|}
\hline \multirow{2}{*}{$\begin{array}{c}\text { Experi- } \\
\text { ment } \\
\text { no. }\end{array}$} & \multicolumn{3}{|c|}{ Plasma } & \multicolumn{2}{|c|}{ Collected perfusate } & \multirow[b]{2}{*}{$\mathrm{C} / \mathrm{I}_{\mathrm{In}}$} \\
\hline & $\mathrm{pH}$ & {$\left[\mathrm{HCO}_{3}^{-}\right]$} & Pcon & pH & {$\left[\mathrm{HCO}_{3}^{-}\right]$} & \\
\hline & & $m E q / L$ & $m m \mathrm{Hg}$ & & $m E q / L$ & \\
\hline \multirow[t]{3}{*}{21} & 7.48 & 34.9 & 48 & 6.94 & 10.9 & 1.12 \\
\hline & & & & 7.03 & 13.4 & 0.82 \\
\hline & 7.60 & 37.5 & 39 & 7.10 & 15.7 & 1.13 \\
\hline \multirow[t]{4}{*}{22} & 7.37 & 33.0 & 59 & 7.20 & 19.8 & 1.02 \\
\hline & & & & 7.07 & 14.7 & 0.97 \\
\hline & & & & 7.18 & 18.9 & 1.02 \\
\hline & 7.72 & 47.2 & 38 & 7.31 & 25.5 & 1.03 \\
\hline \multirow[t]{4}{*}{23} & 7.45 & 30.5 & 45 & 7.05 & 14.0 & 1.01 \\
\hline & & & & 7.08 & 15.0 & 1.03 \\
\hline & & & & 7.11 & 16.1 & 0.97 \\
\hline & 7.70 & 42.7 & 36 & 6.90 & 9.9 & 1.04 \\
\hline 24 & 7.65 & 43.3 & 41 & 6.94 & 10.9 & 1.01 \\
\hline \multirow[t]{5}{*}{25} & 7.41 & 27.4 & 45 & 6.84 & 8.6 & 1.00 \\
\hline & & & & 7.03 & 13.4 & 0.98 \\
\hline & & & & 6.92 & 10.4 & 1.00 \\
\hline & & & & 6.95 & 11.1 & 0.98 \\
\hline & 7.75 & 44.0 & 33 & 6.81 & 8.1 & 1.00 \\
\hline \multirow[t]{4}{*}{26} & 7.47 & 33.7 & 48 & 7.16 & 18.1 & 1.00 \\
\hline & & & & 7.20 & 19.8 & 1.01 \\
\hline & & & & 7.07 & 14.7 & 1.16 \\
\hline & & & & 7.31 & 25.5 & 0.98 \\
\hline \multirow[t]{2}{*}{27} & 7.54 & 37.2 & 45 & 7.16 & 18.1 & 0.94 \\
\hline & 7.73 & 45.5 & 36 & 7.07 & 14.7 & 0.95 \\
\hline \multirow[t]{4}{*}{28} & 7.52 & 29.4 & 37 & 7.18 & 18.9 & 0.97 \\
\hline & & & & 7.07 & 14.7 & 0.98 \\
\hline & & & & 6.87 & 9.3 & 1.01 \\
\hline & 7.74 & 44.4 & 34 & 7.02 & 13.1 & 0.90 \\
\hline Mean & & & & 7.06 & 14.9 & 1.00 \\
\hline$\pm \mathrm{SD}$ & & & & 0.14 & 4.6 & 0.08 \\
\hline
\end{tabular}

* Carbonic anhydrase was inhibited by intravenous and intralumina administration of CL 11,366.

hyperventilation. ${ }^{3}$ The average $\mathrm{HCO}_{3}{ }^{-}$concentration in the collected perfusate was slightly higher than in the animals with intact enzyme activity, but the difference was not statistically significant $(\mathrm{p}>0.8)$. Urinary $\mathrm{pH}$, on the other hand, rose from a control value of 6.19 to 7.58 after enzyme inhibition, indicating that the drug had a potent effect on the free flowing tubules. The absence of any significant effect on the isolated perfused tubules probably means that $\mathrm{H}^{+}$secretion was at minimal levels under these experimental conditions, and further that the total accumulation of $\mathrm{HCO}_{3}{ }^{-}$was also small.

${ }^{3}$ It is also possible that hyperventilation was the result of a cerebrospinal fluid acidosis. This might occur by delayed dehydration of $\mathrm{H}_{2} \mathrm{CO}_{3}$, similar to the mechanism in the proximal tubule (1), if carbonic anhydrase is present at the interface between blood and spinal fluid.
Induction of acute metabolic alkalosis in the presence of an intact carbonic anhydrase system resulted in only a slight rise in the $\mathrm{pH}$ and $\mathrm{HCO}_{3}^{-}$ concentration of the perfusate (Table IV). With a comparable degree of metabolic alkalosis, inhibition of carbonic anhydrase resulted in a significantly greater recovery of $\mathrm{HCO}_{3}{ }^{-}$than in any of the other three groups of animals $(p<0.001)$.

The composition of the perfusion fluid used in the experiments in Tables II to V was such that no net absorption of water (or sodium) occurred. Under these conditions, the effects of solute flux asymmetry and solvent drag are minimized or eliminated (11). It is possible to conclude, therefore, that the rise in $\mathrm{HCO}_{3}{ }^{-}$concentration during perfusion was not due simply to absorption of water. The question arises, however, whether net reabsorption of solute and water as occurs during free flow might prevent $\mathrm{HCO}_{3}{ }^{-}$influx. For example, bulk movement of water might create a solvent drag effect in which flux of ions in the direction opposite to the flow of water is impeded (12). In order to examine this possibility, we used an isotonic $\mathrm{NaCl}$ perfusion fluid in the experiments shown in Table VI. As can be seen, in most of the collections, much more $\mathrm{HCO}_{3}^{-}$was recovered than can be attributed to absorption of water from the original perfusion fluid, indicating that $\mathrm{HCO}_{3}^{-}$accumulation was occurring in spite of bulk flow of water. The variable rise in inulin and $\mathrm{HCO}_{3}{ }^{-}$concentration may have been due in part to differences in the length of the perfused segments (13).

TABLE VI

Accumulation of bicarbonate in an isotonic $\mathrm{NaCl}$ perfusate*

\begin{tabular}{cccc}
\hline \hline $\begin{array}{c}\text { Perfusion } \\
\text { no. }\end{array}$ & pH & {$\left[\mathrm{HCO}_{3}{ }^{-}\right]$} & $\mathrm{C} / \mathrm{I}_{\mathrm{In}}$ \\
\hline & & $m E q / L$ \\
1 & 7.02 & 10.5 & 1.59 \\
2 & 6.56 & 3.7 & 1.28 \\
3 & 6.01 & 1.0 & 1.15 \\
4 & 6.98 & 9.6 & 1.25 \\
5 & 5.94 & 0.9 & 1.17 \\
6 & 6.72 & 5.3 & 1.43 \\
7 & 6.20 & 1.6 & 1.10 \\
8 & 6.63 & 4.3 & 1.33 \\
9 & 6.75 & 5.7 & 1.78 \\
10 & 6.82 & 6.7 & 1.90 \\
\end{tabular}

* Data were obtained from four normal rats. Carbonic anhydrase was inhibited by intravenous and intraluminal administration of CL 11,366. 


\section{Discussion}

The results of the present study indicate that $\mathrm{HCO}_{3}{ }^{-}$can gain access to the proximal tubular lumen from a source distal to the glomerulus. When isolated segments of cortical proximal tubules of normal rats were perfused with a solution containing less than $0.2 \mathrm{mEq}$ per $\mathrm{L}$ of $\mathrm{HCO}_{3}{ }^{-}$and from which there was no net absorption of sodium or water, the $\mathrm{HCO}_{3}{ }^{-}$concentration rose to about $3 \mathrm{mEq}$ per L. Inhibition of renal carbonic anhydrase did not significantly alter the recovery of $\mathrm{HCO}_{3}{ }^{-}$in the perfusate in normal animals, but when the enzyme was inhibited in acutely alkalotic animals, $\mathrm{HCO}_{3}^{-}$recovery increased to a mean value of $15 \mathrm{mEq}$ per $\mathrm{L}$. Considering that the time of contact of the perfusion fluid with the tubular epithelium was only about 10 seconds, the concentrations of $\mathrm{HCO}_{3}{ }^{-}$found in each of the experimental groups may be slightly lower than the true steady state concentrations, and the magnitude of the postglomerular addition of $\mathrm{HCO}_{3}^{-}$ might be underestimated to some degree by the present observations.

The precise mechanism of the addition of $\mathrm{HCO}_{3}{ }^{-}$ to the luminal fluid cannot be established with certainty from these data, but several possibilities may be considered. In the discussion that follows, reference will be made to the following series of reactions, which are thought to occur within the lumen of the proximal tubule ${ }^{4}$ :

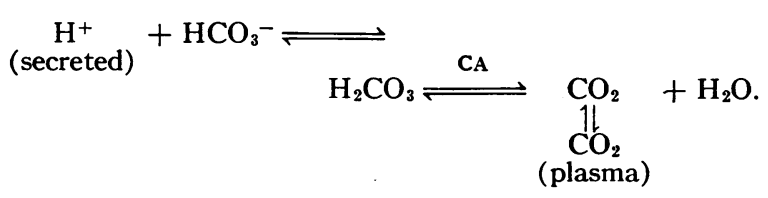

First, $\mathrm{HCO}_{3}^{-}$may have been generated in the tubular lumen due to either passive or active transfer of $\mathrm{H}^{+}$out of the lumen or to addition of $\mathrm{OH}^{-}$ from the epithelial cells. Either of these processes would have the effect of shifting the above series of reactions toward the left, and, because of the ready availability of $\mathrm{CO}_{2}$, generating new bicarbonate ions. However, this explanation seems unlikely for two reasons. It has been shown that carbonic anhydrase is accessible to the fluid in the proximal tubule in rats and that its inhibition

\footnotetext{
${ }^{4}$ Carbonic anhydrase (CA) may actually catalyze the reaction $\mathrm{HCO}_{3}^{-} \stackrel{\mathrm{CA}}{\rightleftharpoons} \mathrm{CO}_{2}+\mathrm{OH}^{-}$, but the conclusions drawn in the Discussion would be the same.
}

results in an acid disequilibrium $\mathrm{pH}$ in the lumen, due to continued net secretion of $\mathrm{H}^{+}$and delayed dehydration of intraluminal $\mathrm{H}_{2} \mathrm{CO}_{3}$ (1). Movement of $\mathrm{H}^{+}$out of the lumen or of $\mathrm{OH}^{-}$into the lumen as a mechanism for $\mathrm{HCO}_{3}^{-}$generation would lead to an alkaline disequilibrium $\mathrm{pH}$ in the enzyme-inhibited animals, contrary to the observed effect of carbonic anhydrase inhibition (1). More important, however, is the fact that inhibition of carbonic anhydrase markedly increased the recovery of $\mathrm{HCO}_{3}{ }^{-}$in the alkalotic animals (Table $\mathrm{V}$ vs. Table IV). It is clear from the above reactions that generation of new $\mathrm{HCO}_{3}^{-}$from $\mathrm{CO}_{2}$, whether due to removal of $\mathrm{H}^{+}$or addition of $\mathrm{OH}^{-}$ from the cells, should be reduced whenever intraluminal carbonic anhydrase is inhibited. Our observations in alkalotic rats are thus incompatible with this hypothesis. Although the combination of alkalosis and enzyme inhibition may have increased the alkalinity of the tubular cells to a greater degree than did alkalosis alone, and therefore enhanced the movement of $\mathrm{OH}^{-}$from cell to tubular lumen, the absence of intraluminal carbonic anhydrase activity would be expected to slow the reaction

$$
\mathrm{CO}_{2}+\mathrm{OH}^{-} \longrightarrow \mathrm{HCO}_{3}^{-}
$$

drastically and thereby limit the formation of $\mathrm{HCO}_{3}{ }^{-}$. Thus, transfer of $\mathrm{H}^{+}$out of the lumen or transfer of $\mathrm{OH}^{-}$into the lumen seems inadequate to explain the data.

A second hypothesis is that molecular $\mathrm{NH}_{3}$ and possibly the cations of weak organic bases or anions of weak organic acids entered the perfusion fluid by a process of nonionic diffusion (14-16). In doing so, they would tend to combine with free $\mathrm{H}^{+}$in solution, as for example in the reaction

$$
\mathrm{NH}_{3}+\mathrm{H}^{+} \longrightarrow \mathrm{NH}_{4}{ }^{+} \text {, }
$$

and thereby liberate $\mathrm{OH}^{-}$. This would result in the generation of an equivalent amount of $\mathrm{HCO}_{3}{ }^{-}$ by the reaction

$$
\mathrm{OH}^{-}+\mathrm{CO}_{2} \stackrel{\mathrm{CA}}{\longrightarrow} \mathrm{HCO}_{3}{ }^{-} \text {. }
$$

Since $\mathrm{pH}$ gradients determine to a large extent the distribution of weak acids and bases across semipermeable membranes $(17,18)$, it might be expected that the largest intraluminal accumulation of $\mathrm{NH}_{3}$ occurred in those experiments in which the tubular cells were most alkaline relative 
to the in situ $\mathrm{pH}$ of the perfusion fluid, i.e., the alkalotic rats in which carbonic anhydrase had been inhibited. Although $\mathrm{NH}_{3}$ diffusion may have been favored under these experimental conditions, generation of $\mathrm{HCO}_{3}^{-}$from $\mathrm{OH}^{-}$and $\mathrm{CO}_{2}$ should have been markedly impaired, due to the inhibition of intraluminal carbonic anhydrase. Thus, as discussed in the preceding section, the observation that $\mathrm{HCO}_{3}^{-}$recovery increases rather than decreases in the presence of carbonic anhydrase inhibition argues against generation of $\mathrm{HCO}_{3}{ }^{-}$ intraluminally from $\mathrm{OH}^{-}$.

The experimental observations seem to be best explained by influx of ionic bicarbonate, either from the tubular cells or from the peritubular capillary blood. It would be expected if this were the mechanism that the amount of $\mathrm{HCO}_{3}{ }^{-}$recovered in the perfusate would vary inversely with the rate of $\mathrm{H}^{+}$secretion by the tubular cells. This was clearly the case in the alkalotic rats, in which inhibition of carbonic anhydrase and subsequent reduction in $\mathrm{H}^{+}$secretion markedly increased the recovery of $\mathrm{HCO}_{3}{ }^{-}$in the perfusate (Table $\mathrm{V}$ ), presumably because less of the entering ionic bicarbonate was converted into $\mathrm{CO}_{2}$ and $\mathrm{H}_{2} \mathrm{O}$ during the perfusion period. The absence of any clear-cut response to carbonic anhydrase inhibition in normal rats (Table III) could also be explained by this mechanism, if it is assumed that $\mathrm{HCO}_{3}{ }^{-}$influx was much smaller when plasma $\mathrm{HCO}_{3}{ }^{-}$concentration was normal and that, consequently, the rate of $\mathrm{H}^{+}$secretion was at minimal levels. According to this interpretation, the magnitude of $\mathrm{HCO}_{3}{ }^{-}$influx would be influenced by either the transcellular or transtubular concentration gradient of bicarbonate ions. Since in the alkalotic animals with an intact carbonic anhydrase system the residual concentration of $\mathrm{HCO}_{3}^{-}$in the collected perfusate was almost as low as in normal rats (Table IV vs. Table II), it could be concluded that $\mathrm{HCO}_{3}{ }^{-}$influx is dependent upon the intracellular $\mathrm{HCO}_{3}^{-}$concentration and that acute alkalosis did not produce a significant intracellular rise within the time of the experiment. The combination of alkalosis and carbonic anhydrase inhibition might have produced a greater rise in intracellular $\mathrm{HCO}_{3}^{-}$. Alternatively, $\mathrm{HCO}_{3}^{-}$influx could have increased in the alkalotic animals with an intact carbonic anhydrase system, but $\mathrm{H}^{+}$ secretion also increased in direct proportion to the larger amount of $\mathrm{HCO}_{3}^{-}$entering the lumen. This view is compatible with the suggestion that, because of the availability of carbonic anhydrase to the proximal tubular fluid, the rate of $\mathrm{H}^{+}$secretion in this segment of the nephron varies directly with the buffer content of the luminal fluid and is not limited by steep $\mathrm{pH}$ gradients (1).

If our conclusion is correct that ionic bicarbonate leaked into the tubular lumen, this ion would be behaving in a manner similar to sodium, potassium, and chloride, which have all been shown to diffuse back into the lumen of the rat proximal tubule (2-4). The precise mechanism (or mechanisms) accounting for the influx of these ions is presently uncertain, and it is not clear whether the leak occurs at the luminal membrane or through aqueous channels passing either through or between the cells (19). Evidence for the presence of extracellular aqueous channels has been found by Windhager and Klose (20) in Necturus kidney tubules, but whether similar shunt pathways exist in rat kidney tubules or in other species is unknown. Thus, the relative importance of intracellular vs. extracellular ion concentrations and of electrical potentials in influencing ionic influx cannot be stated at this time.

The conclusion that the proximal tubular epithelium is permeable to $\mathrm{HCO}_{3}{ }^{-}$raises the possibility that flux of this ion may be a component of the over-all handling of $\mathrm{HCO}_{3}^{-}$by the kidney. Although net accumulation of $\mathrm{HCO}^{-}$in the tubular lumen might not occur under ordinary free flow conditions, there could nevertheless be a significant influx of the ion opposite to the direction of net reabsorption. Since in the present experiments the magnitude of influx appeared to vary directly with the concentration gradient (either transtubular or transcellular), the importance of an influx component would be expected to depend upon the particular experimental conditions. In any event, inward movement of $\mathrm{HCO}_{3}{ }^{-}$ would have to be considered in estimates of the actual kinetics of $\mathrm{H}^{+}$secretion at the tubular level. Further studies seem indicated to determine the precise role of flux of ionic bicarbonate in various physiological and pathological conditions.

\section{References}

1. Rector, F. C., Jr., N. W. Carter, and D. W. Seldin. The mechanism of bicarbonate reabsorption in the 
proximal and distal tubules of the kidney. J. clin. Invest. 1965, 44, 278.

2. Kashgarian, M., H. Stöckle, C. W. Gottschalk, and K. J. Ullrich. Transtubular electrochemical potentials of sodium and chloride in proximal and distal renal tubules of rats during antidiuresis and water diuresis (diabetes insipidus). Pflügers Arch. ges. Physiol. 1963, 277, 89.

3. Giebisch, G., R. M. Klose, G. Malnic, W. J. Sullivan, and E. E. Windhager. Sodium movement across single perfused proximal tubules of rat kidneys. J. gen. Physiol. 1964, 47, 1175.

4. Marsh, D. J., K. J. Ullrich, and G. Rumrich. Micropuncture analysis of the behavior of potassium ions in rat renal cortical tubules. Pflügers Arch. ges. Physiol. 1963, 277, 107.

5. Sonnenberg, H., and P. Deetjen. Methode zur Durchströmung einzelner Nephronabschnitte. Pflügers Arch. ges. Physiol. 1964, 278, 669.

6. Thurau, K., and P. Deetjen. Intratubular urine flow rates and transtubular water flux in parts of the individual mammalian nephron. Free communication no. 255. 22nd International Physiological Congress, Leiden, 1962.

7. Marsh, D., and C. Frasier. Reliability of inulin for determining volume flow in rat renal cortical tubules. Amer. J. Physiol. 1965, 209, 283.

8. Bank, N. Relationship between electrical and hydrogen ion gradients across the rat proximal tubule. Amer. J. Physiol. 1962, 203, 577.

9. Windhager, E. E., and G. Giebisch. Micropuncture study of renal tubular transfer of sodium chloride in the rat. Amer. J. Physiol. 1961, 200, 581.

10. Travis, D. M., C. Wiley, B. R. Nechay, and T. H. Maren. Selective renal carbonic anhydrase inhibition without respiratory effect: pharmacology of 2-benzenesulfonamido-1,3,4-thiadiazole-5-sulfonamide (CL 11,366). J. Pharmacol. exp. Ther. 1964, $143,383$.

11. Giebisch, G., and E. E. Windhager. Renal tubular transfer of sodium, chloride and potassium. Amer. J. Med. 1964, 36, 643.

12. Koefoed-Johnsen, V., and H. H. Ussing. Ion transport in Mineral Metabolism, C. L. Comar and F. Bronner, Eds. New York, Academic Press, 1960, p. 169.

13. Windhager, E. E., K. Hierholzer, and M. Wiederholt. Microperfusion study of reabsorption of $\mathrm{Na}$ and fluid in single proximal tubules of rat kidneys. Fed. Proc. 1966, 25, 459.

14. Glabman, S., R. M. Klose, and G. Giebisch. Micropuncture study of ammonia excretion in the rat. Amer. J. Physiol. 1963, 205, 127.

15. Hayes, C. P., Jr., J. S. Mayson, E. E. Owen, and R. R. Robinson. A micropuncture evaluation of renal ammonia excretion in the rat. Amer. J. Physiol. 1964, 207, 77.

16. Hayes, C. P., Jr., E. E. Owen, and R. R. Robinson. Renal ammonia excretion during acetazolamide or sodium bicarbonate administration. Amer. J. Physiol. 1966, 210, 744.

17. Orloff, J., and R. W. Berliner. The mechanism of the excretion of ammonia in the dog. J. clin. Invest. 1956, 35, 223.

18. Milne, M. D., B. H. Scribner, and M. A. Crawford. Non-ionic diffusion and the excretion of weak acids and bases. Amer. J. Med. 1958, 24, 709.

19. Windhager, E. E., and G. Giebisch. Electrophysiology of the nephron. Physiol. Rev. 1965, 45, 214.

20. Windhager, E. E., and R. M. Klose. Measurements of electrical conductances in single proximal tubules of Necturus kidney. Fed. Proc. 1965, 24, 520. 